\title{
Introduction to the special issue on the Flatreef PGE-Ni-Cu deposit, northern limb of the Bushveld Igneous Complex
}

\author{
Wolfgang D. Maier ${ }^{1}$ (1) $\cdot$ Marina Yudovskaya ${ }^{2} \cdot$ Pedro Jugo $^{3}$ \\ Received: 19 June 2020 / Accepted: 4 November 2020 / Published online: 2 December 2020 \\ (C) The Author(s) 2020
}

\begin{abstract}
More than 30 years ago, Cox and Singer (1986) suggested that magmatic platinum-group element (PGE)-Ni-Cu deposits are amongst the best understood of ore deposits, yet the origin of PGE mineralization in the Bushveld Igneous Complex (BIC) remains controversial after a century of study. In the northern limb of the BIC, the unravelling of ore formation proved particularly difficult due to relatively poor outcrop, which is typically affected by contamination of the intruding magmas with the host rocks and expressed in the form of abundant xenoliths, footwall rafts and disturbance of magmatic stratigraphy. In this thematic issue, we present contributions on the Flatreef, a recently discovered world-class PGE-Ni-Cu deposit constituting a downdip extension of the mineralized unit of the Platreef of the northern limb. Two deep shafts are currently being sunk, making the Flatreef one of the most significant new mine development on the Bushveld in several decades.
\end{abstract}

\section{Stratigraphy of the Bushveld northern limb and definitions of the Platreef and Flatreef}

The detailed stratigraphic relationship between the Platreef and the Flatreef and potential stratigraphic correlations between both horizons with the Upper Critical Zone (UCZ) in the western and eastern limbs of the Bushveld Complex have been debated for years. One reason for this is the lack of consistent definitions for the terms Platreef and Flatreef. In the following section, we first review the current use of both terms in the context of the broader stratigraphic framework of the Bushveld northern limb and then propose updated definitions.

After nearly 100 years of study, it is now widely recognized that in the northern limb (Figs. 1, 2) all major stratigraphic zones constituting the Rustenburg Layered Suite (RLS) have different thicknesses, chemical composition and mineralogy

Editorial handling: G. Beaudoin

Wolfgang D. Maier

MaierW@cardiff.ac.uk

Cardiff University, Cardiff, UK

University of the Witwatersrand, Johannesburg, South Africa

3 Laurentian University, Sudbury, ON, Canada than equivalent units in the remainder of the Bushveld Igneous Complex.

In the western and eastern Bushveld limbs, the Marginal Zone comprises a compositionally and texturally diverse suite of intrusives (gabbronorite, norite, pyroxenite, harzburgite) forming either sills in the floor or a contact layer at the base of the main Bushveld layered body (Sharpe 1981; Cawthorn et al. 1981). The Marginal Zone has been suggested to be relatively poorly developed within the northern limb (Kinnaird et al. 2005; Grobler et al. 2019). However, this may be partly due to terminology. Firstly, noritic and pyroxenitic sills that likely represent the Marginal Zone have in the past been included within the Platreef. Secondly, ultramafic sills enclosed in sedimentary and granitic floor rocks have been grouped into the Lower Zone. Thus, the lowermost parts of the Platreef (or the so-called Lower Platreef; Manyeruke et al. 2005; Kinnaird et al. 2005; Ihlenfeld and Keays 2011) that are bordered by sedimentary rocks in their floor and roof could instead be considered to be part of the Marginal Zone. Recent work by Yudovskaya et al. (this volume) shows that mafic sills underlying the Lower Zone are widespread in the northern limb, and their relics are recognized as the so-called brown norite and recrystallized norite, respectively. However, the temporal relationships for specific sills remain unconstrained. 
The Lower Zone (LZ) is developed along most of the strike of the northern limb and cannot be readily correlated with the LZ elsewhere as it contains massive chromitites and PGE-mineralized zones. Its thickness has likely been influenced by floor topography and tectonism. The zone reaches $1700 \mathrm{~m}$ on the farm Grasvally (Hulbert and von Grunewaldt 1982) and over $800 \mathrm{~m}$ on Turfspruit (Yudovskaya et al. 2013). At most localities, the Lower Zone (rather than the Platreef) composes the basal cumulate unit of significant thickness in the northern limb, and it is separated from the overlying Platreef by sedimentary inlayers or rafts up to $300-\mathrm{m}$ thick (Hulbert and von Gruenewaldt 1982; Maier et al. 2008; Yudovskaya et al. 2013). Where in direct contact with the Platreef, the upper boundary of the LZ is defined as the top of the uppermost thick plagioclase-poor harzburgite, as has been suggested for the western limb (Teigler and Eales 1996).

In the western and eastern limbs, the Critical Zone hosts the 13 main chromitite seams of the Bushveld Complex (lower group, middle group and upper group) and the main PGE reefs (UG2 and Merensky Reef). In those limbs, the Critical Zone is approximately 1000-m thick and subdivided into a lower portion (LCZ) consisting mainly of pyroxenite and harzburgite (Cameron 1978; Teigler and Eales 1996) and an upper portion (UCZ) featuring repetitive cyclic units of cumulates that are progressively more evolved with height, i.e. in the ideal case chromitite-harzburgite-pyroxenitenorite-anorthosite (Eales et al. 1988). In the northern limb, the LCZ appears to be absent, whereas the UCZ that is now normally equated with the Platreef is much more contaminated and sulfide enriched than elsewhere, and somewhat depleted in chromite.

It is instructive to consider the evolving meaning of the term Platreef. Hans Merensky, the discoverer of the Bushveld PGE reefs in 1925, believed that the stratiform PGE orebody of the northern limb represents a thickened lateral equivalent of the Merensky Reef as exposed in the western and eastern Bushveld (Wagner 1929; Cawthorn 2015). In contrast, van der Merwe (1976) considered the mineralized interval, for which he coined the term Platreef, to constitute the base of the Main Zone, despite equating the Platreef with the "Platinum Horizon" of Wagner (1929). With increasing geological knowledge due to extensive exploration, mining and research activities, particularly since the opening of Mogalakwena mine in 1990, it became clear that the Platreef may contain multiple concordant and discordant sills and corresponds to a zone rather than a layer. Thus, in the recent literature, the term Platreef has been used to denote either the whole stratigraphic interval between the LZ and the Main Zone in the northern limb (Kinnaird and McDonald 2005; McDonald and Holwell 2011) or only the mineralized portion thereof (van der Merwe 1976, 1978; Viljoen and Schurmann 1998).

One of the earliest definitions of the Platreef was provided by Gain and Mostert (1982; p. 1396) who described the Platreef as "composed of a complex sequence of medium- to coarse-grained pyroxenites, melanorites, and norites, in places pegmatoidal and serpentinized, containing metasedimentary xenoliths of the floor rocks". Using the data accumulated since the 1990s, Kinnaird and McDonald (2005; p. 196) defined the Platreef as "Mafic units enriched in Ni-Cu-PGE that occur between the Archaean granite-gneiss basement or the Transvaal Supergroup and the gabbronorites of the Main Zone, north of the Planknek Fault". This definition essentially interprets the Platreef as the correlative of the entire UCZ, but it excludes the Ni-Cu-PGE mineralization south of the Planknek-Ysterberg Fault (termed the GNPA member by Hulbert and von Gruenewaldt 1982), based on the fact that the stratigraphy in this area is more correlatable with the Bushveld eastern and western limbs, including a massive chromitite regarded as the UG2 equivalent (Hulbert and Von Gruenewaldt 1982; Maier et al. 2008; Smith et al. 2014; Kinnaird and Nex 2015). Given the presence of the UG2-like chromitite on Turfspruit (Grobler et al. 2019; Langa et al. 2020) and Akanani (Yudovskaya et al. 2011), this argument is not applicable anymore, and, therefore, the GNPA member south of the Planknek Fault should be accepted as a southern facies of the Platreef and a stratigraphic equivalent of the Upper Critical Zone (Kinnaird and McDonald 2018).

The definition by Kinnaird and McDonald (2005) also did not include the mineralization occurring in the northern portion of the northern Bushveld limb, notably at the Aurora project on the farms Altona, Kransplaats, La Pucella, Luge, Nonnenwerth, Non Plus Ultra and Schaffhausen. This area is regarded as the northern facies of the Platreef by Manyeruke (2007) and Maier et al. (2008), whereas McDonald et al. (2017) and McFall et al. (2019) argue that because the geochemical and mineral characteristics are consistent with Main Zone compositions, this mineralization should not be included in the Platreef.

Maier et al. (2008) suggested that all mineralized rocks at the base of the northern limb should be termed "Platreef" arguing that this definition provides a clear exploration guideline that can be applied in the field, without the need of geochronology or geochemistry. However, this definition does not help distinguish between contact-style and internal reef-style PGE mineralization that may occur at the basal and 
Fig. 1 Geological map of the Rustenburg Layered Suite of the Bushveld Igneous Complex (after Mungall et al. 2016) showing locations mentioned in this issue and other relevant locations

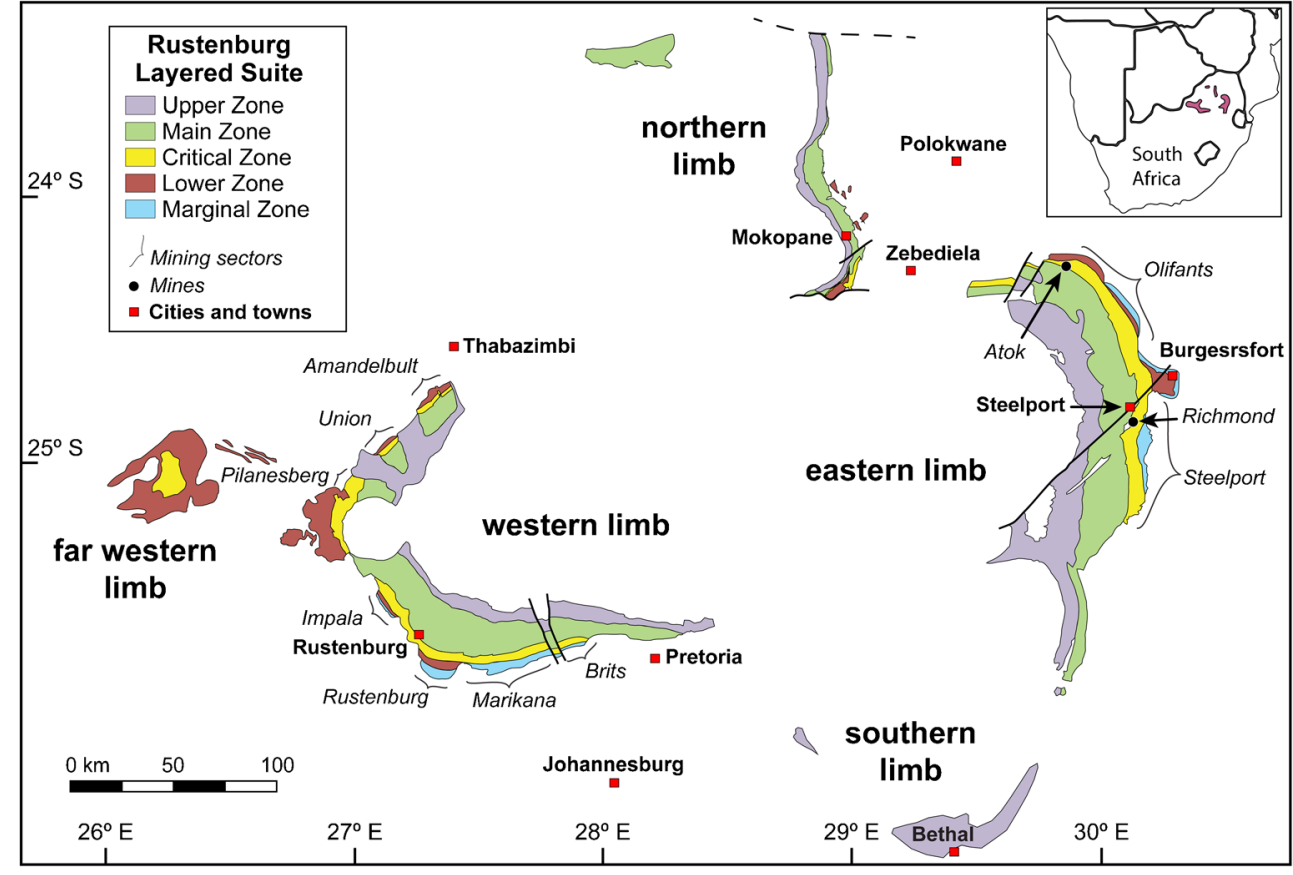

in the top parts of the Platreef, respectively, as seen in the Flatreef sequence on Turfspruit (Grobler et al. 2019). In other areas of the northern limb, these two types of mineralization are superimposed and may form a thick high-grade orebody, as seen on Sandsloot where high-grade ores occur both in intrusive and metasedimentary rocks (McDonald and Holwell 2011; Klemd et al. 2016; Mwenze et al. 2019).

Other problems with the definitions by Kinnaird and McDonald (2005) and Maier et al. (2008) are as follows: (i) both encompass the PGE mineralization in the Lower Zone, e.g. on Grasvally, Turfspruit and Uitloop, with other areas remaining poorly explored; (ii) so far, the known stratigraphy of the Platreef does not include undisputable Lower Critical Zone rocks, unless the Akanani deeper sections could be considered to represent this (Mitchell and Scoon 2012; Scoon et al. 2020). However, the presence of LCZ in the deep western portions of the northern limb cannot be excluded, and any definition of the Platreef (and Flatreef) should be flexible enough to allow a potential inclusion of LCZ in the future; (iii) both definitions do not include the thick unmineralized or poorly mineralized portions of the Platreef that can be a predominant constituent of the sequence.

Scoon et al. (2020) suggested to use the term "Platreef Unit" for the entire sequence correlative of the Critical Zone (Mitchell and Scoon 2012), whereas the term "Platreef" should be reserved for the mineralized part or an orebody within the sequence. To our mind this approach represents a useful compromise. We thus propose the following new definition: The Platreef Unit of the Bushveld northern limb is a complex sequence composed of coalescing magmatic units, some of which representing sills, with enclosed metasedimentary inlayers that represents a contaminated analogue of the chromite-bearing Upper Critical Zone of the western and eastern Bushveld and is overlain by chromite-free Main Zone rocks. It is pervasively, yet irregularly PGE mineralized, with economic PGE deposits defined as Platreef deposits. The top contact with the Main Zone is a key characteristic to distinguish the Platreef Unit from mafic-ultramafic marginal sills and satellite bodies crystallized from Critical Zone magmas but emplaced completely into 


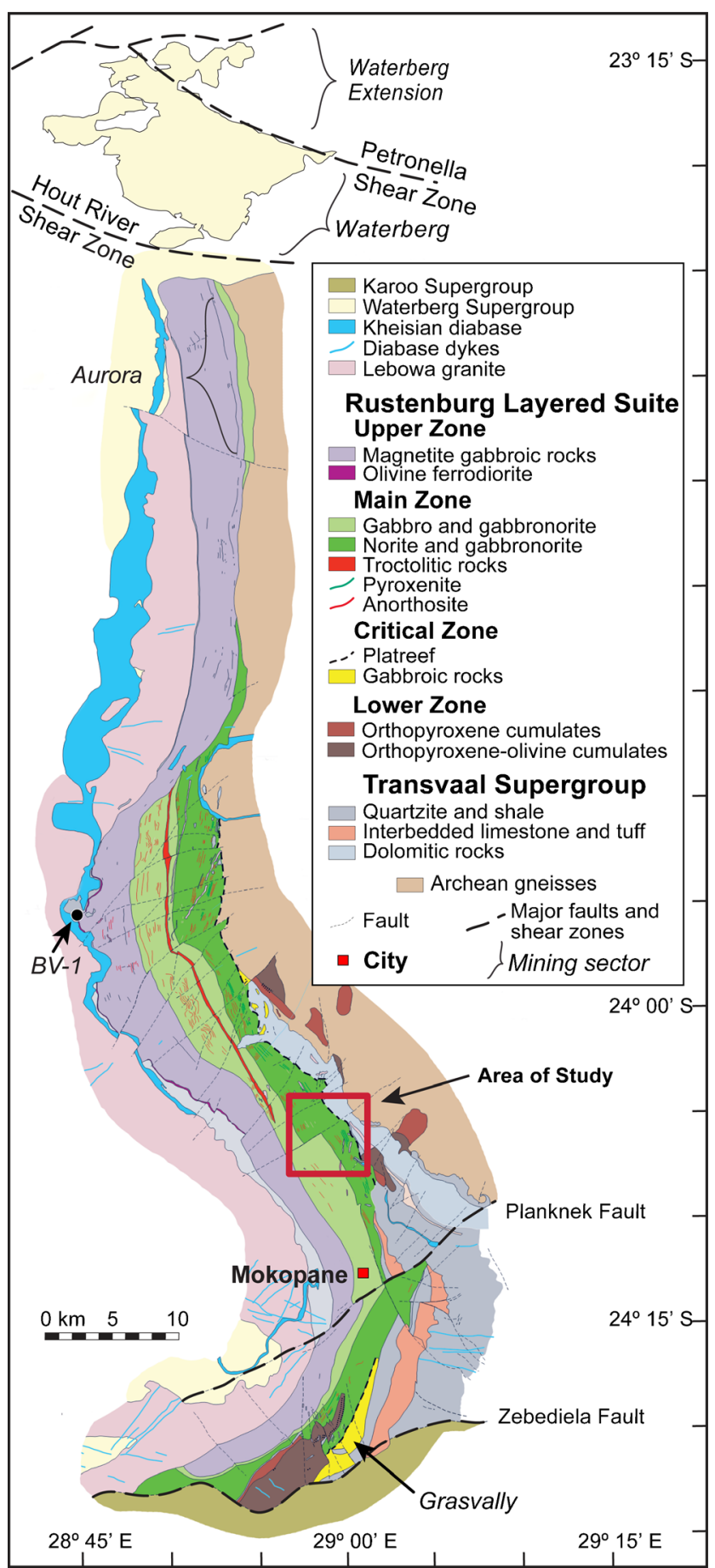

Fig. 2 Geological map of the northern limb after (after Ashwal et al. 2005) and the Waterberg extension (after Yudovskaya et al. 2018) showing the area of study in this issue and several other relevant locations sedimentary wallrocks and not having the Main Zone roof. The Flatreef Unit represents the deep western facies of the Platreef Unit (or the Critical Zone as a synonym, Grobler et al. 2019), characterized by a change in dip, decreasing amount of contamination and less disturbance of magmatic stratigraphy (Fig. 3 ). The Flatreef includes several lower-rank units and sub-units, with some of the uppermost ones representing the thick facies PGE reef correlatives of the Merensky and Bastard reefs. This facies concept has proven to be a useful tool to correlate layers in the western and eastern limbs (Eales et al. 1988, Viljoen 1999; Maier and Teigler 1995, Maier and Eales 1997) and it should be further developed for the northern limb with particular attention being paid to regional markers aiming to see similarities rather than differences which are often of a secondary character.

The base of the 3-km-thick Main Zone (MZ) is usually delineated by a sharp contact to distinctive layers of mottled (poikilitic) anorthosite which form the uppermost unit of the UCZ. In the centre of the MZ is the troctolite unit, which does not appear in the Main Zone elsewhere in the Bushveld Complex (van der Merwe 1976; Kennedy 2019). In contrast, the Pyroxenite Marker (PM), which marks a pronounced isotopic and trace element shift at the top of the Main Zone in the eastern and western Bushveld, was thought to be absent in the northern limb (Ashwal et al. 2005; Tanner et al. 2019). However, Maier and Barnes et al. (2010) correlate PGE rich layers on Moorddrift with the PM, and Cawthorn (2020) suggested that a lateral equivalent of the PM does exist in the Bellevue drill core and reflects an addition of a relatively unevolved magma (Fig. 2).

The Upper Zone (UZ) in the northern limb is $<1.2-\mathrm{km}$ thick (Ashwal et al. 2005) and contains $\sim 32$ discrete magnetitite layers which can be traced along the strike of the northern limb and within the Villa Nora fragment to the northwest. Ashwal et al. (2005) suggested that the boundary between the Upper and Main Zones should be identified by a sharp increase in magnetic susceptibility that is caused by the presence of significant modal magnetite. This approach was adopted during the Waterberg project exploration to postulate the presence of UZ (with PGE mineralization at 


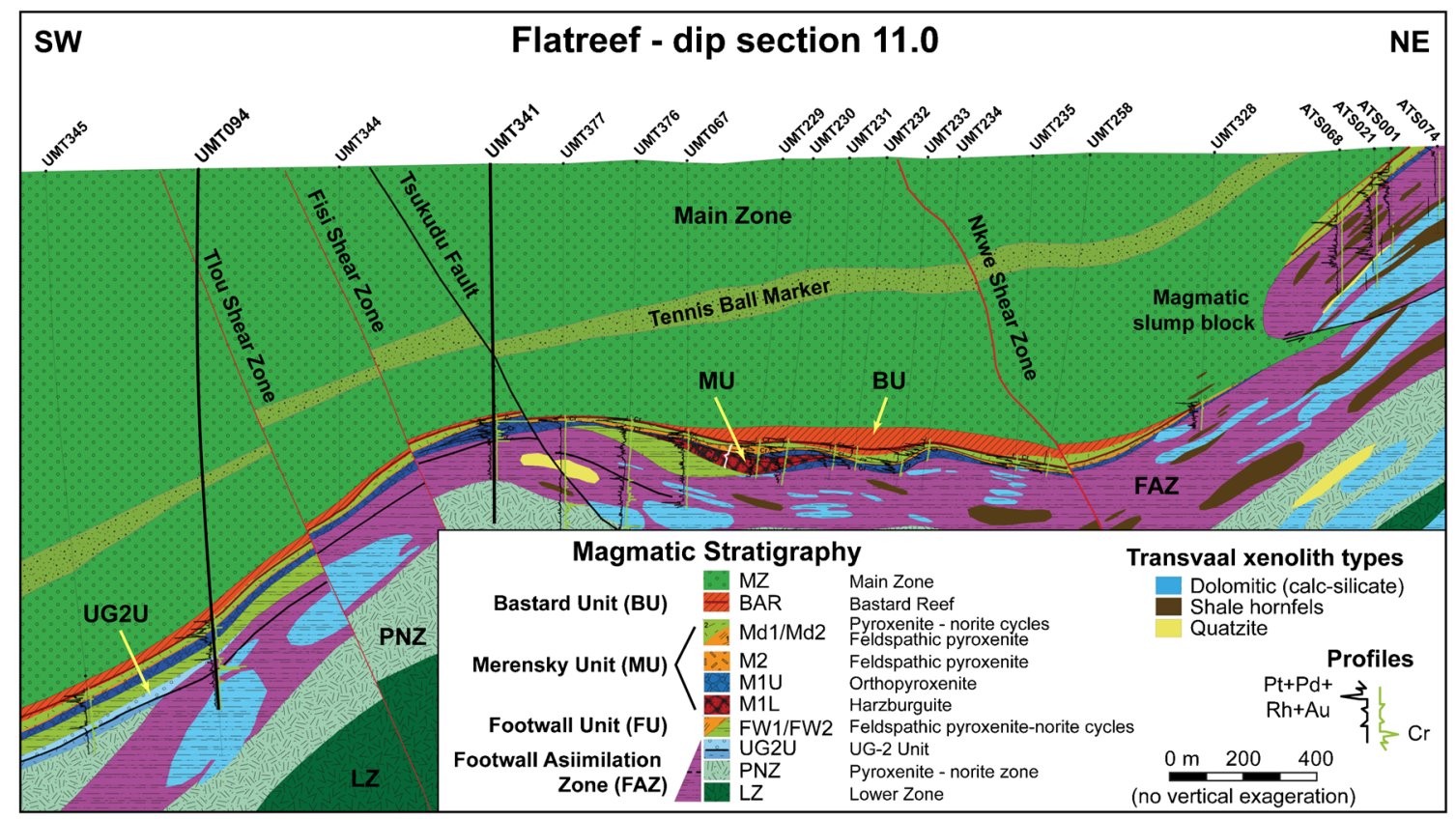

Fig. 3 Representative cross section through the Platreef in the Turfspruit area showing the change in dip that defines the Flatreef (after Grobler et al. 2019). Two of the drillholes used in contributions to this issue are in bold

its base) in the uppermost portion of the exposed stratigraphy (Kinnaird et al. 2017, and Huthmann et al. 2018).

The Waterberg project is of particular note because, in addition to the Flatreef, it represents a further example of a recent discovery of significant new PGE deposits in the Bushveld. In the Waterberg project, the RLS includes an ultramafic portion with a composition very similar to that of the uncontaminated ultramafic part of the Platreef (e.g. on Turfspruit, Yudovskaya et al. 2017; Grobler et al. 2019) and a gabbroic to troctolitic portion that has a homogeneous $\mathrm{Sr}$ isotope composition reminiscent of the UZ showing progressively more UZ-like chemical characteristics upwards, such as increased disseminated magnetite contents (Kinnaird et al. 2017; Huthmann et al. 2017). The possible PGE fertility of the UZ magmas has previously been hypothesized by von Gruenewaldt (1976). However, the UZ of the Waterberg project area lacks massive magnetite which led Kinnaird et al. (2017) to suggest that the RLS segment north of the Hout River Shear Zone (HRSZ) was developed as a separate magmatic basin fed from a distinct crustal sub-chamber at the rifted edge of the craton.

Both the ultramafic and the gabbroic-troctolitic portions contain intervals of high-grade, low-sulfide PGE mineralization, referred to as $\mathrm{F}$ zone (in the ultramafic rocks) and $\mathrm{T}$ zone (in gabbroic rocks) (McCreesh et al. 2018). Preliminary data suggest that these two contrasting styles of mineralization are also recognizable immediately south across the HRSZ on the farm
Harriet's Wish (van Scheltema 2019). The T zone can be potentially correlated with Main Zone-hosted troctolite marker mineralization (van der Merwe 1976, 1978) studied on the farm Vogelstruisfontein (Kennedy 2019) and mineralized melagabbro and pyroxenite layers on Moorddrift, $20 \mathrm{~km}$ to the $\mathrm{S}$ of Mokopane (Maier and Barnes 2010).

\section{Brief overview of petrogenetic models for the Bushveld PGE reefs}

A common thread of most of the previously published petrogenetic models for the Bushveld PGE reefs is the assumption that the PGE were originally concentrated by magmatic sulfides. However, the trigger for sulfide melt saturation and segregation remains debated. Two main models can be distinguished: Advocates of Model 1 suggest that sulfide melt saturation occurred within the Bushveld magma chamber. Proposed triggers for sulfide melt saturation include the following:

i. Chromite crystallization resulting in a decrease in $\mathrm{Fe}$ content of the magma (Vermaak 1976). However, the amount of chromite in the known exposures of the Merensky Reef, Platreef and Flatreef is relatively small (usually $<1-2 \%$ ), and it is unclear whether the 
resulting decrease in Fe content is sufficient to trigger sulfide saturation.

ii. Mixing of relatively light replenishing magma with denser resident magma (Campbell et al. 1983; Naldrett and von Gruenewaldt 1989). The sulfide melt segregated through, and equilibrated with, a large body of silicate melt, thereby achieving large $\mathrm{R}$ factors (mass ratio of silicate melt to sulfide melt) and high metal tenors. However, Li and Ripley (2005) showed that magma mixing can trigger sulfide melt saturation only if both mixing end members are nearly sulfide saturated, yet the available data from the presumed parent magmas of the Bushveld Complex suggest that the magmas were strongly S undersaturated (Barnes et al. 2010).

iii. Fractionation of the magma in the chamber leading to saturation in a sulfide liquid and accumulation of the sulfide liquid at the top of the cumulate pile (Barnes et al. 2010). However, as the cotectic ratio of sulfides forming from Bushveld magmas is likely $<1 \%$ (Cawthorn 2005), a further step is required to concentrate the sulfides to levels observed in the reefs (commonly 2 4\%; Barnes and Maier 2002, McDonald and Holwell 2011).
Fig. 4 Detailed geological map of the area of study showing the location of the drillholes documented in this issue. The location of Shaft \#1 and the boundaries of the Turfspruit and Macalacaskop farms are also shown

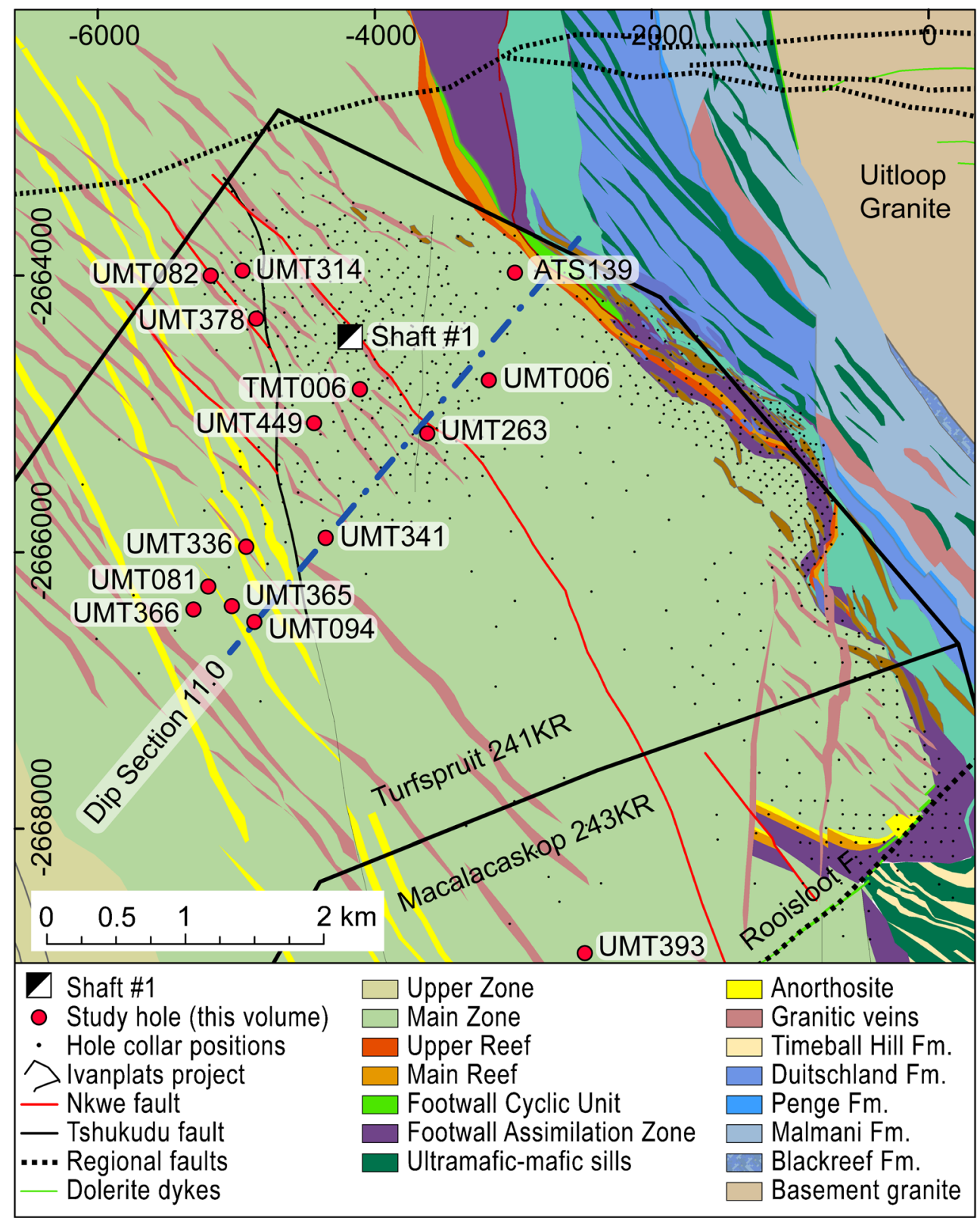


iv. To address this problem, Maier et al. (2013) proposed a hydrodynamic model in which sulfides were concentrated by phase sorting and kinetic sieving, in response to seismically induced slumping and fluidization of crystal slurries during filling of the magma chamber. The model was experimentally tested by Forien et al. (2015) using circular beads as crystal analogues, but it remains to be examined whether lath-like particles that constitute a closer analogue to plagioclase and pyroxene crystals would behave differently.

v. Nucleation of sulfides at the crystallisation front near the top of the cumulate pile and collection of PGE from magma flowing past the sulfide (Latypov et al. 2017). Similar challenges as for trigger mechanism (ii) apply, i.e. known Bushveld magmas are strongly sulfide undersaturated.

vi. Mobilization and concentration of early formed cumulus sulfide and PGE by late magmatic fluids (Boudreau and McCallum 1992). However, the available evidence suggests that some of the PGE concentrated in the reefs (notably Ir, $\mathrm{Ru}, \mathrm{Rh}$ ) are highly immobile under normal magmatic conditions.

The proponents of Model 2 argue that sulfide saturation was reached in a staging chamber below the main Bushveld chamber, triggered by contamination and/or fractionation. The sulfides were entrained and partially resorbed during continued magma ascent, resulting in sulfide and PGE rich magmas being emplaced into the Bushveld chamber, followed by segregation of the sulfides to form the reefs (Lee and Butcher 1990; Mitchell and Scoon 2007; Naldrett et al. 2009; Latypov et al. 2017). The model has been particularly popular for the Platreef (Lee 1996; McDonald and Holwell 2007; Holwell et al. 2011) because the total amount of PGE in the Platreef would require a complementary magma column of up to $10 \mathrm{~km}$ of overlying PGE depleted magma (at least in a simplistic 2D model). However, cumulates and residual liquids may have migrated towards the interior or the periphery of the chamber. Another problem with Model 2, as with some of the proposed mechanisms listed under Model 1 above, is that there is presently no evidence for PGE or sulfide-rich parent magmas to the Bushveld Complex although numerous fine-grained sills and several chilled margins have been studied (Davies and Tredoux 1985; Barnes et al. 2010; Wilson et al. 2015; Maier et al. 2016). However, the available data are all from the western and eastern Bushveld, and thus more work is required to study the marginal suite in the northern limb.

\section{Contributions in this thematic issue}

In the papers within this thematic issue, we present a large amount of new data for the Flatreef based on the study of the extensive drill core archive of Ivanplats. The locations of the drillholes used in the studies in this issue are shown in Figure 4. Most of the papers are based on research presented first at the northern limb session during the 13th International Platinum Symposium held in Limpopo, South Africa, in JuneJuly 2018. The efforts of the organizing committee in carrying out field excursions and coreyard visits are gratefully acknowledged.

Maier et al. (2020) focus on the petrogenesis of the most highly mineralized portion of the Flatreef, namely, the interval between the MZ and the base of the Merensky Reef. Based on a detailed examination of four drill cores, they propose that the combination of several favourable processes, including country rock assimilation as well as hydrodynamic and hydromagmatic processes, resulted in exceptionally thick mineralized intervals (e.g. $22 \mathrm{~m}$ at $>8 \mathrm{ppm}$ in UMT378).

Langa et al. (2020) compare the UG2 chromitite in the Flatreef with a UG2 reference suite from the western Bushveld using a range of techniques including petrography, electron probe microanalysis, laser ablationinductively coupled plasma-mass spectrometry and Mössbauer spectroscopy. They conclude that whereas semi-massive and disseminated chromitite may have a variable composition due to equilibration with trapped silicate melt, the massive portions of the seams have overlapping compositions.

Yudovskaya et al. (2020) conducted a detailed petrographic and compositional study of the interaction between the intruding Lower Zone magmas and the anhydrite-rich country rocks in drill core UMT336. The study shows that contact metamorphism and partial melting may result in the formation of hybrid rocks with $\mathrm{Sr}$ isotope characteristics similar to those of the pristine magmatic counterparts.

The papers by Mayer et al. (2020) and Beukes et al. (2020) present the first $\mathrm{Sr}$ isotopic profiles of the Flatreef on the farms Turfspruit (Mayer et al.) and Macalacaskop (Beukes et al.). Both studies document a similar $\mathrm{Sr}$ isotopic stratigraphy and range in initial $\mathrm{Sr}$ isotope ratio as previously documented in the Merensky Reef interval of the western Bushveld by Kruger and Marsh (1985).

Keir-Sage et al. (2020) present a detailed S isotopic profile of the Flatreef as intersected in deep drill core 
UTM94. The authors show that the lower portion of the Flatreef has $\delta^{34} \mathrm{~S}$ values up to $+8 \%$ o suggesting strong contamination by the country rocks, whereas the upper portions, including the proposed correlatives of the Merensky and Bastard reefs, have $\delta^{34} \mathrm{~S}$ values of +2 to $+4 \%$ overlapping with the uppermost Critical Zone of the western Bushveld.

In summary, papers in this thematic issue provide support for correlation between the Flatreef of the northern limb and the uppermost Critical Zone in the remainder of the Bushveld Complex while also documenting strong contamination of the Flatreef rocks by the country rocks.

Open Access This article is licensed under a Creative Commons Attribution 4.0 International License, which permits use, sharing, adaptation, distribution and reproduction in any medium or format, as long as you give appropriate credit to the original author(s) and the source, provide a link to the Creative Commons licence, and indicate if changes were made. The images or other third party material in this article are included in the article's Creative Commons licence, unless indicated otherwise in a credit line to the material. If material is not included in the article's Creative Commons licence and your intended use is not permitted by statutory regulation or exceeds the permitted use, you will need to obtain permission directly from the copyright holder. To view a copy of this licence, visit http://creativecommons.org/licenses/by/4.0/.

\section{References}

Ashwal LD, Webb SJ, Knoper MW (2005) Magmatic stratigraphy in the Bushveld northern lobe: continous geophysical and mineralogical data from the $2950 \mathrm{~m}$ Bellevue drillcore. S Afr J Geol 108:199-232

Barnes S-J, Maier WD (2002) Platinum-group elements and microstructures of normal Merensky Reef from Impala Platinum Mines, Bushveld complex. J Petrol 43:103-128

Barnes S-J, Maier WD, Curl EA (2010) Composition of the marginal rocks and sills of the Rustenburg Layered Suite, Bushveld Complex, South Africa: implications for the formation of the platinum-group element deposits. Econ Geol 105:1491-1511

Beukes JJ, Roelofse F, Gauert CDK, Grobler DF, Ueckermann H (2020) Strontium isotope variations in the Flatreef on Macalacaskop, 1 northern limb, Bushveld Complex: Implications for the source of PGEs in the Merensky Reef. Mineral Deposita. https://doi.org/10. 1007/s00126-020-00998-2

Boudreau AE, McCallum IS (1992) Concentration of platinum-group elements by magmatic fluids in layered intrusions. Econ Geol 87: $1830-1848$

Cameron EN (1978) The lower zone of the eastern Bushveld Complex in the Olifants River trough. J Petrol 19:437-462

Campbell IH, Naldrett AJ, Barnes SJ (1983) A model for the origin of the platinum-rich sulfide horizons in the Bushveld and Stillwater Complexes. J Petrol 24:133-165

Cawthorn RG (2005) Contrasting sulphide contents of the Bushveld and Sudbury Igneous Complexes. Mineral Deposita 40:1-12
Cawthorn RG (2015) A review of the Bushveld complex and its mineralisation. In: Hammond NQ, Hatton C (eds) Platinum-group element (PGE) mineralisation and resources of the Bushveld Complex. Council for Geoscience, Pretoria, pp 17-92

Cawthorn RG (2020) Massive pyroxene compositional oscillations on a metre scale in the Pyroxenite Marker, northern limb, Bushveld Complex, South Africa. Lithos 356:105392

Cawthorn RG, Davies G, Clubley-Armstrong A, McCarthy TS (1981) Sills associated with the Bushveld Complex, South Africa. Lithos 14:1-15

Cox DP, Singer DA (1986) Mineral deposit models. Bulletin 1693. US Geological Survey, Reston

Davies G, Tredoux M (1985) The platinum-group element and gold contents of the marginal rocks and sills of the Bushveld Complex. Econ Geol 80:838-848

Eales HV, Field M, de Klerk WJ, Scoon RN (1988) Regional trends of chemical variation and thermal erosion in the Upper Critical Zone, western Bushveld Complex. Min Mag 52:63-79

Forien M, Tremblay J, Barnes S-J, Burgisser A, Page P (2015) The role of viscous particle segregation in forming chromite layers from slumped crystal slurries: insights from analogue experiments. J Petrol 56:2425-2444

Gain SB, Mostert AB (1982) The geological setting of the platinoid and base metal sulfide mineralization in the Platreef of the Bushveld Complex in Drenthe, north of Potgietersrus. Econ Geol 77:13951404

Grobler DF, Brits JAN, Maier WD, Crossingham A (2019) Litho-and chemostratigraphy of the Flatreef PGE deposit, northern Bushveld Complex. Mineral Deposita 54:3-28

Holwell DA, McDonald I, Butler IB (2011) Precious metal enrichment in the Platreef, Bushveld Complex, South Africa: evidence from homogenized magmatic sulfide melt inclusions. Contrib Mineral Petrol 161:1011-1026

Hulbert LJ, von Gruenewaldt G (1982) Nickel, copper, and platinum mineralization in the lower zone of the Bushveld Complex, south of Potgietersrus. Econ Geol 77:1296-1306

Huthmann FM, Kinnaird JA, Yudovskaya MA, Elburg MA (2017) The Sr isotopic stratigraphy of the far northern Bushveld Complex. S Afr J Geol 120:499-510

Huthmann FM, Yudovskaya MA, Kinnaird JA, McCreesh M, McDonald I (2018) Geochemistry and PGE of the lower mineralized zone of the Waterberg project, South Africa. Ore Geol Rev 92:161-185

Ihlenfeld C, Keays RR (2011) Crustal contamination and PGE mineralization in the Platreef, Bushveld Complex, South Africa: evidence for multiple contamination events and transport of magmatic sulfides. Mineral Deposita 46:813-832

Keir-Sage E, Leybourne MI, Jugo PJ, Grobler DF (2020) Assessing the extent of local assimilation 1 within the Platreef, northern limb of the Bushveld Igneous Complex, using sulfur isotopes and trace element geochemistry. Mineral Deposita. https://doi.org/10.1007/s00126020-01024-1

Kennedy B (2019) Unconventional olivine-rich cumulates, magma dynamics and development of platinum-group element mineralisation in the Main Zone of the northern Bushveld Complex. Cardiff University, PhD Dissertation, $457 \mathrm{p}$

Kinnaird JA, McDonald I (2005) An introduction to mineralisation in the northern limb of the Bushveld Complex. Appl Earth Sci 114:194 198

Kinnaird JA, McDonald I (2018) The northern limb of the Bushveld Complex: a new economic frontier. Soc Econ Geol Spec Publ 21: 157-176 
Kinnaird JA, Nex PAM (2015) An overview of the Platreef. Platinumgroup element (PGE) mineralisation and resources of the Bushveld complex, South Africa. Mineral Resour Ser 2:193-342

Kinnaird JA, Hutchinson D, Schurmann L, Nex PAM, de Lange R (2005) Petrology and mineralisation of the southern Platreef: northern limb of the Bushveld Complex, South Africa. Mineral Deposita 40:576597

Kinnaird JA, Yudovskaya M, McCreesh M, Huthmann F, Botha TJ (2017) The Waterberg platinum group element deposit: atypical mineralization of mafic-ultramafic rocks of the Bushveld Complex, South Africa. Econ Geol 112:1367-1394

Klemd R, Herderich T, Junge M, Oberthür T, Schouwstra R, Roberts J (2016) Platinum-group element concentrations in base-metal sulphides from the Platreef, Mogalakwena Platinum Mine, Bushveld Complex, South Africa. S Afr J Geol 119:623-638

Kruger FJ, Marsh JS (1985) The mineralogy, petrology and origin of the Merensky cyclic unit in the western Bushveld Complex. Econ Geol 80:958-974

Langa MM, Jugo PJ, Leybourne MI, Grobler DF, Adetunji J, Skogby H (2020) Chromite chemistry of a massive chromitite seam in the northern limb of the Bushveld Igneous Complex, South Africa: correlation with the UG-2 in the eastern and western limbs and evidence of variable assimilation of footwall rocks. Mineral Deposita. https://doi.org/10.1007/s00126-020-00964-y

Latypov R, Chistyakova S, Barnes SJ, Hunt EJ (2017) Origin of platinum deposits in layered intrusions by in situ crystallization: evidence from undercutting Merensky Reef of the Bushveld Complex. J Petrol 58:715-761

Lee CA (1996) A review of mineralization in the Bushveld complex and some other layered intrusions. In: Cawthorn RG (ed) Layered intrusions. Elsevier, Amsterdam, pp 103-145

Lee CA, Butcher AR (1990) Cyclicity in the Sr isotope stratigraphy through the Merensky and Bastard Reefs, Atok Section, eastern Bushveld Complex. Econ Geol 85:877-883

Li C, Ripley EM (2005) Empirical equations to predict the sulfide content of mafic magmas at sulfide saturation and applications to magmatic sulfide deposits. Mineral Deposita 40:218-230

Maier WD, Barnes S-J (2010) The petrogenesis of platinum-group element reefs in the upper Main zone of the northern lobe of the Bushveld Complex on the farm Moorddrift, South Africa. Econ Geol 105:841-854

Maier WD, Eales HV (1997) Correlation within the UG2-Merensky Reef interval of the Western Bushveld Complex, based on geochemical, mineralogical and petrological data. Geol Surv S Afr Bull 120:56

Maier WD, Teigler B (1995) A facies model for the Western Bushveld Complex. Econ Geol 90:2343-2349

Maier WD, de Klerk L, Blaine J, Manyeruke T, Barnes S-J, Stevens MVA, Mavrogenes JA (2008) Petrogenesis of contact-style PGE mineralization in the northern lobe of the Bushveld complex: comparison of data from the farms Rooipoort, Townlands, Drenthe and Nonnenwerth. Mineral Deposita 43:255-280

Maier WD, Barnes S-J, Groves DI (2013) The Bushveld Complex, South Africa: formation of platinum-palladium, chrome-and vanadiumrich layers via hydrodynamic sorting of a mobilized cumulate slurry in a large, relatively slowly cooling, subsiding magma chamber. Mineral Deposita 48:1-56

Maier WD, Barnes S-J, Karykowski BT (2016) A chilled margin of komatiite and Mg-rich basaltic andesite in the western Bushveld Complex, South Africa. Contrib Mineral Petrol 171:57

Maier WD, Abernethy KEL, Grobler DF, Moorhead G (2020) Formation of the Flatreef deposit, northern Bushveld, by hydrodynamic and hydromagmatic processes, Mineral Deposita. https://doi.org/10. 1007/s00126-020-00987-5

Manyeruke TD (2007) Geochemical variation of the Platreef in the northern limb of the Bushveld Complex: implications for the origin of the
PGE mineralization (Doctoral dissertation, $\mathrm{PhD}$ thesis, University of Pretoria)

Manyeruke TD, Maier WD, Barnes SJ (2005) Major and trace element geochemistry of the Platreef on the farm Townlands, northern Bushveld complex. South Afr J Geol 108:381-396

Mayer CC, Jugo PJ, Leybourne MI, Grobler DF (2020) Strontium isotope stratigraphy through the Platreef at Turfspruit, northern limb of the Bushveld Igneous Complex: evidence of correlation between the Platreef and the Merensky Reef. Mineral Deposita. https://doi.org/ 10.1007/s00126-020-01006-3

McCreesh MJG, Yudovskaya MA, Kinnaird JA, Reinke C (2018) Platinum-group minerals of the $\mathrm{F}$ and $\mathrm{T}$ zones, Waterberg Project, Far Northern Bushveld Complex: implication for the formation of the PGE mineralisation. Mineral Mag 82:539-575

McDonald I, Holwell DA (2007) Did lower zone magma conduits store PGE-rich sulphides that were later supplied to the Platreef? S Afr J Geol 110:611-616

McDonald I, Holwell DA (2011) Geology of the northern Bushveld Complex and the setting and genesis of the Platreef Ni-Cu-PGE deposit. Rev Econ Geol 17:297-327

McDonald I, Harmer RJ, Holwell DA, Hughes HS, Boyce AJ (2017) CuNi-PGE mineralisation at the Aurora Project and potential for a new PGE province in the Northern Bushveld Main Zone. Ore Geol Rev 80:1135-1159

McFall K, McDonald I, Tanner D, Harmer RE (2019) The mineralogy and mineral associations of platinum-group elements and precious metals in the Aurora $\mathrm{Cu}-\mathrm{Ni}-\mathrm{Au}-\mathrm{PGE}$ deposit, northern limb, Bushveld Complex. Ore Geol Rev 106:403-422

Mitchell AA, Scoon RN (2007) The Merensky Reef at Winnaarshoek, eastern Bushveld Complex: a primary magmatic hypothesis based on a wide reef facies. Econ Geol 102:971-1009

Mitchell AA, Scoon RN (2012) The Platreef of the Bushveld Complex, South Africa: a model of multiple, non-sequential magma replenishment based on observations at the Akanani Project. S Afr J Geol 115:535-550

Mungall JE, Kamo SL, McQuade S (2016) U-Pb geochronology documents out-of-sequence emplacement of ultramafic layers in the Bushveld Igneous Complex of South Africa. Nat Commun 7(13385):1-13

Mwenze T, Okujeni C, Frei D, Siad A, Bailie R (2019) Geochemical controls on the distribution of PGE mineralisation in skarns during emplacement of the Platreef in the northern limb of the Bushveld Complex, South Africa. J Geochem Explor 205:106340

Naldrett AJ, von Gruenewaldt G (1989) Association of platinum group elements with chromitite in layered intrusions and ophiolite complexes. Econ Geol 84:180-187

Naldrett AJ, Wilson A, Kinnaird J, Chunnett G (2009) PGE tenor and metal ratios within and below the Merensky Reef, Bushveld Complex: implications for its genesis. J Petrol 50:625-659

Scoon RN, Costin G, Mitchell A, Moine B (2020) Non-sequential injection of PGE-rich ultramafic sills in the Platreef unit at Akanani, northern limb of the Bushveld Complex: evidence from $\mathrm{Sr}$ and $\mathrm{Nd}$ isotopic systematics. J Petrol. https://doi.org/10.1093/petrology/ egaa032

Sharpe MR (1981) The chronology of magma influxes to the eastern compartment of the Bushveld Complex, as exemplified by its marginal border group. J Geol Soc Lond 138:307-326

Smith JW, Holwell DA, McDonald I (2014) Precious and base metal geochemistry and mineralogy of the Grasvally Norite-PyroxeniteAnorthosite (GNPA) member, northern Bushveld Complex, South Africa: implications for a multistage emplacement. Mineral Deposita 49:667-692

Tanner D, McDonald I, Harmer REJ, Muir DD, Hughes HSR (2019) A record of assimilation preserved by exotic minerals in the lowermost platinum-group element deposit of the Bushveld Complex: the Volspruit Sulphide zone. Lithos 324-325:584-608 
Teigler B, Eales HV (1996) The lower and critical zones of the western limb of the Bushveld Complex, as indicated by the Nooitgedacht boreholes. Geol Surv S Afr Bull 111:126

van der Merwe MJ (1976) The layered sequence of the Potgietersrus limb of the Bushveld complex. Econ Geol 71:1337-1351

van der Merwe MJ (1978) The geology of the basic and ultramafic rocks of the Potgietersrus limb of the Bushveld Complex. PhD Dissertation, Univ Witwatersrand, $176 \mathrm{p}$

Van Scheltema J (2019) Mineralisation in the northern limb of the Bushveld Complex, Harriet's Wish farm. MSc dissertation, Univ Witwatersrand, $286 \mathrm{p}$

Vermaak CF (1976) The Merensky Reef - thoughts on its environment and genesis. Econ Geol 71:1270-1298

Viljoen MJ (1999) The nature and origin of the Merensky Reef of the western Bushveld Complex based on geological facies and geophysical data. S Afr J Geol 102:221-239

Viljoen MJ, Schurmann LW (1998) Platinum-group metals. In: MGC W, Anhaeusser CR (eds) The mineral resources of South Africa: Handbook, vol 16. Council for Geosciences, Pretoria, pp 532-568

Von Gruenewaldt G (1976) Sulfides in the upper zone of the Eastern Bushveld Complex. Econ Geol 71:1324-1336

Wagner PA (1929) The platinum deposits of the Bushveld Complex. Oliver and Boyd, Edinburgh, p 588

Wilson AH (2015) The earliest stages of emplacement of the eastern Bushveld Complex: development of the Lower Zone, Marginal Zone and Basal Ultramafic Sequence. J Petrol 56:347-388
Yudovskaya M, Kinnaird J, Naldrett AJ, Mokhov A, McDonald I, Reinke C (2011) Facies variation in PGE mineralization in the Central Platreef, Bushveld Complex. Can Mineral 49:1349-1384

Yudovskaya MA, Kinnaird JA, Sobolev AV, Kuzmin DV, McDonald I, Wilson AH (2013) Petrogenesis of the lower zone olivine-rich cumulates beneath the Platreef and their correlation with recognized occurrences in the Bushveld Complex. Econ Geol 108:1923-1952

Yudovskaya MA, Kinnaird JA, Grobler DF, Costin G, Abramova VD, Dunnett T, Barnes S-J (2017) Zonation of Merensky-style platinumgroup element mineralization in turfspruit thick reef facies (Northern limb of the Bushveld complex). Econ Geol 112:1333-1365

Yudovskaya MA, Sluzhenikin SF, Costin G, Shatagin KN, Dubinina EO, Grobler DF, Ueckermann H, Kinnaird JA (2018) Anhydrite assimilation by ultramafic melts of the Bushveld Complex, and its consequences to petrology and mineralization. Metals Miner Soc 21:177206

Yudovskaya MA, Costin G, Sluzhenikin SF, Kinnaird JA, Ueckermann H, Abramova VD, Grobler DF (2020) Hybrid norite and the fate of argillaceous to anhydritic shales assimilated by Bushveld melts. Miner Deposita. https://doi.org/10.1007/s00126-020-00978-6

Publisher's note Springer Nature remains neutral with regard to jurisdictional claims in published maps and institutional affiliations. 